\title{
PENGGUNAAN MODEL E-LEARNING DALAM MENINGKATKAN HASIL BELAJAR MAHASISWA PADA MATERI MICROPROCESSOR
}

(Studi Empiris Pada Mahasiswa Semester IV Program Studi Teknik Komputer

Politeknik Sains dan Teknologi Wiratama Maluku Utara Tahun 2016)

\section{USE OF E-LEARNING MODEL IN IMPROVING STUDENT'S RESULTS IN MICROPROCESSOR MATERIALS}

(The Empirical Study in Fourth Semester of Student's Computer Science Engineering Programs of Politeknik Sains dan Teknologi Wiratama Maluku Utara 2016)

\author{
Muharto $^{1}$, Syahril Hasan ${ }^{2}$, Arisandy Ambarita ${ }^{3}$ \\ Program Studi Manajemen Informatika, \\ Politeknik Sains dan Teknologi Wiratama Maluku Utara \\ muhartolaode@gmail.com
}

\begin{abstract}
Abstrak
Penelitian ini bertujuan untuk menganalisis dan mendeskripsikan perbedaan hasil belajar mahasiswa yang menggunakan model e-learning dalam pembelajara materi microprocessor di Politeknik Sains dan Teknologi Wiratama Maluku Utara. Metode yang digunakan eksperimen semu (Quasi Eksperimen Design) dengan pola noequivalent control group design. Penelitian diawali dengan pemberian pretest untuk mengetahui kondisi awal sampel penelitian, dilanjutkan dengan pemberian perlakuan. Perlakuan yang diberikan adalah penerapan pembelajaran menggunakan e-Learning pada kelompok eksperimen dan penerapan pembelajaran tanpa $e$-Learning pada kelompok kontrol. Kemudian dilanjutkan dengan postest untuk mengetahui hasil akhir pembelajaran. Hasil penelitian membuktikan adanya perbedaan hasil belajar antara kelompok eksperimen dan kelompok kontrol. Pada kelompok eksperimen 83,33\% siswa yang mencapai kategori sangat baik sedangkan pada kelompok kontrol tidak ada yang mencapai kategori sangat baik. Uji hipotesis menggunakan mann whitney U (two independent samples $\mathrm{T}$ test), diperoleh nilai $\mathrm{U}=200,500 ; \mathrm{W}=696,500 ; \mathrm{Z}-3,958$, dan Asymp sig. $0,000<\alpha=0,05$, sehingga $\mathrm{H}_{0}$ ditolak dan $\mathrm{H}_{1}$ diterima. Artinya, terdapat perbedaan signifikan terhadap hasil belajar siswa pada kelompok eksperimen dan kelompok kontrol. Kelompok e-learning lebih effektif hasil belajarnya daripada kelas tanpa e-learning. Oleh karena itu, perlu adanya penerapan model e-Learning dala pembelajaran khususnya pada materi microprocessor.
\end{abstract}

Kata kunci: Model e-learning, microprocessor dan hasil belajar

\begin{abstract}
This study aims to analyze and describe differences in student learning outcomes using e-learning model in the learning of microprocessor materials in Politeknik Sains dan Teknologi Wiratama Maluku Utara. The method used quasi experiment with pattern
\end{abstract}


noequivalent control group design. The research begins with the provision of pretest to determine the initial condition of the study sample, followed by treatment. The treatment provided is the application of learning using E-Learning in the experimental group and the application of learning without E-Learning in the control group. Then proceed with the postest to find out the end result of learning. The results of this study prove the difference of learning outcomes between the experimental group and the control group. In the experimental group $83.33 \%$ of students who achieved very good category while in the control group no one reached the category very well. Hypothetical test using mann whitney $U$ (two independent samples $T$ test), obtained value $U=200,500 ; W=696,500 ; Z-3.958$, and Asymp sig.0,000 $<\alpha$ $=0.05$, so $\mathrm{HO}$ is rejected and $\mathrm{Hl}$ accepted. That is, there are significant differences in student learning outcomes in the experimental and control groups. E-learning groups are more effective in learning outcomes than classes without E-learning. Therefore, it is necessary to apply E-Learning model in learning especially on microprocessor material.

\section{Keywords: E-learning model, microprocessor and learning results}

\section{PENDAHULUAN}

Pengetahuan tentang arsitektur microprocessor sangat diperlukan dalam proses pembelajaran khususnya pada program studi teknik komputer. Namun demikian, materi kuliah ini dianggap sulit diajarkan karena dosen harus memiliki kemampuan yang memadai untuk mengajarkan mata kuliah tersebut. Dosen dituntut kreatif dan inovatif menangani kesulitan belajar siswa. Dosen dalam mengajarkan materi yang monoton, kurang inovatif dan kurang menantang kreatifitas siswa menjadi salah satu sebab kegagalan proses pembelajaran. Akibatnya, proses belajar mengajar sangat membosankan dan miskin improvisasi.

Menurut pengamatan peneliti pada saat melakukan pra penelitian, tingkat keaktifan mahasiswa pada saat mengikuti mata kuliah arsitektur microprocessor dapat dikategorikan rendah, karena mahasiswa sudah beranggapan bahwa pelajaran tersebut sangat sulit dan juga harus didukung dengan fasilitas yang memadai agar tercapai tujuan pembelajaran. Hal ini berdampak pada rendahnya kemampuan siswa dalam memahami materi pelajaran yang ditunjukkan dengan nilai teori dan praktek baik individual maupun klasikal di bawah $60 \%$. Pada saat itu peneliti mengamati metode yang digunakan dalam mengajar masih bersifat konvensional dimana dosen menerangkan materi dan melakukan praktik kemudian mahasiswa disuruh mengikuti dosen untuk mempraktikkan di komputer (laboratorium), sehingga mahasiswa dalam kelas masih kurang aktif disamping banyak waktu yang terbuang.

Untuk mengatasi masalah-masalah tersebut, perlu mencari metode pembelajaran yang sesuai. Salah satu metode pembelajaran yang dianggap mampu mengatasi rendahnya pencapaian target minimal kompetensi mahasiswa pada pelajaran arsitektur microprocessor adalah dengan menggunakan e-learning. Hal ini karena dalam e-learning kelangsungan proses pembelajaran secara efektif yang dihasilkan dengan cara menggabungkan penyampaian materi secara digital yang terdiri dari dukungan dan layanan dalam belajar (Mayub, 2004). Salah satu ciri e-learning ialah kemampuannya untuk menghasilkan tingkat kecermatan yang tinggi dalam mencapai sasaran belajar. Melalui akumulasi penguasaan sejumlah sasaran belajar yang dirancang secara cermat, siswa terbantu untuk berpikir secara runtut, 
kritis, dan sistematis dalam menghadapi fenomena-fenomena alam dan lingkungan sekitar. Di samping itu, melalui program pembelajaran yang dikembangkan dalam e-learning ini, guru akan dipandu dalam memilih dan menggunakan metode pembelajaran yang tepat. Di pilihnya e-learning ini dalam pemecahan masalah yang berhubungan dengan peningkatan kualitas pembelajaran pada mata pelajaran teknologi informasi dan komunikasi karena e-learning mempermudah interaksi antara mahasiswa dengan bahan atau materi pelajaran. Demikian juga interaksi antara mahasiswa dengan guru, maupun antara sesama mahasiswa. Hal ini sesuai dengan salah satu prinsip paling penting dari psikologi pendidikan yang menyatakan bahwa guru tidak dapat semata-mata memberikan pengetahuan kepada siswa (Nur dan Wikandari, 2000).

E-learning adalah proses belajar secara efektif yang dihasilkan dengan cara menggabungkan penyampaian materi secara digital yang terdiri dari dukungan dan layanan belajar (Barbara, 2008). Dalam proses pembelajarannya lebih bersifat demokratis dibandingkan dengan kegiatan belajar pada pendidikan konvensional. Kondisi ini disebabkan karena mahasiswa memiliki kebebasan dan tidak merasa khawatir atau ragu-ragu maupun takut, baik untuk mengajukan pertanyaan maupun menyampaikan pendapat atau tanggapan karena tidak ada peserta belajar lainnya yang secara fisik langsung mengamati dan kemungkinan. akan memberikan komentar, meremehkan atau mencemoohkan pertanyaan maupun pernyataannya (Riyanto, 2011).

Pembelajaran dengan menggunakan sistem e-learning sangat baik digunakan dalam proses pembelajaran khususnya mata kuliah teknologi komputer dan informasi.
Namun demikian, masalahnya adalah "apakah e-learning adalah metode yang efektif jika digunakan dalam proses pembelajaran khususnya pada mata pelajaran arsitektur microprocessor. Hal inilah yang menarik untuk dikaji lebih dalam melalui penelitian tentang "Analisis efektivitas penggunaan e-learning dalam meningkatkan hasil belajar mahasiswa pada materi arsitektur microprocessor di Politeknik Sains dan Teknologi Wiratama Maluku Utara".

\section{Rumusan Masalah}

Permasalahan penelitian adalah: bagaimana perbedaan hasil belajar mahasiswa yang menggunakan model e-learning dengan yang tidak menggunakan model e-learning pada materi arsitektur microprocessor di Politeknik Sains dan Teknologi Wiratama Maluku Utara?

\section{LANDASAN TEORI \\ Definisi Teknologi Pendidikan}

Definisi teknologi pendidikan oleh AECT tahun 2004, study "Educational and ethical practice of facilitating learning and improving performance by creating, using, and managing appropriate technological". Dari pengertian ini dapat dimaknai bahwa teknologi Pembelajaran merupakan studi dalam pembelajaran yang dapat meningkatkan kinerja melalui penciptaan, penggunaan, dan pengaturan proses dan sumber daya teknol. Sejalan dengan hal tersebut,

Komisi Teknologi Pembelajaran 1970 yang memberi pengertian lebih umum, teknologi pembelajaran/pendidikan berarti media yang lahir sebagai akibat revolusi komunikasi yang dapat digunakan untuk keperluan pembelajaran disamping guru, buku teks, dan papan tulis. Sedangkan definisi Silber tahun 1970 bahwa teknologi pembelajaran adalah pengembangan (riset, 
desain, produksi, evaluasi, dukungan-pasokan, pemanfaatan) komponen system pembelajaran (pesan, orang, bahan, peralatan, teknik dan latar) serta pengelolaan usaha pengembangan (organisasi dan personil) secara sistematik dengan tujuan untuk memcahkan masalah belajar (Barbara,1994).

Sesuai dengan pengertian di atas, maka kawasan Teknologi pendidikan dibagi menjadi 5 kawasan, yaitu Desain, Pengembangan, Pemanfaatan, Pengelolaan, dan Penilaiaan. Barbara (1994) menjelaskan 5 kawasan tersebut sebagai berikut: 1) Kawasan Desain, mempunyai asal usul dari gerakan psikologi pembelajaran. Desain adalah proses untuk menentukan kondisi belajar. Tujuan desain ialah untuk menciptakan strategi dan produk pada tingkat makro, seperti program dan kurikulum, dan dalam tingkat mikro, seperti pelajaran dan modul. 2) Kawasan Pengembangan, berakar pada produksi media. Melalui proses yang bertahun-tahun perubahan dalam kemampuan media ini kemudian berakibat pada perubahan dalam kawasan. Pengembangan adalah proses penterjemahan spesifikasi desain kedalam bentuk fisik. Didalam kawasan pengembangan terdapat keterkaitan yang kompleks antara teknologi dan teori yang mendorong baik desain pesan maupun startegi pembelajaran. 3) Kawasan Pemanfaatan, pemanfaatan mungkin merupakan kawasan tertua diantara kawasan-kawasan yang lain, karena penggunaan bahan audiovisual secara teratur mendahului meluasnya perhatian terhadap desain dan produksi media pembelajaran yang sistematis. 4) Kawasan Pengelolaan, konsep pengelolaan merupakan bagian intregal dalam bidang teknologi pembelajaran dan dari peran kebanyakan para teknolog pembelajaran. Tujuan yang sesungguhnya dari pengelolaan kasus demi kasus sangat bervariasi, namun keterammpilan pengelolaan yang mendasarinya relative tetap sama apapun kasusnya. Kawasan pengelolaan semula berasal dari administrasi pusat media, program media, dan pelayanan media. Pengelolaan meliputi pengendalian teknologi pembelajaran melalui perencanaan, pengorganisasian, pengkoordinasian, and supervisi. 5) Kawasan Penilaiaan, penilaiaan dalam pengertian yang paling luas adalah aktivitas manusia sehari-hari. Dalam kehidupan sehari-hari kita selalu menakar nilai aktivitas atau kejadian berdasarkan kepada system penilaiaan tertentu. Kawasan penilaiaan tumbuh bersamaan dengan berkembangnya bidang penelitian dan metodologi. Keduanya sering berjalan seiiring bersamaan. Penilaiaan ialah proses penentuan memadai tidaknya pembelajaran dan belajar.

Berdasarkan 5 kawasan di atas, maka penelitian ini termasuk dalam kawasan pemanfaatan, yakni pemanfaatan E-Learning sebagai media pendukung kegiatan pembelajaran pada mata pelajaran Teknologi Informasi dan Komunikasi.

\section{E-Learning}

E-learing merupakan istilah baru sebagai sebuah metode dan media pembelajaran. Ada beberapa pendapat tentang e-learning, yaitu proses belajar yang difasilitasi dan didukung melalui pemanfaatan TIK (Jenkins and Hanson, Center, 2003). E-Learning adalah proses belajar secara efektif yang dihasilkan dengan cara menggabungkan penyampaian materi secara digital yang terdiri dari dukungan dan layanan dalam belajar (Waller, 2001). E-learning "penggunaan teknologi internet untuk mengirimkan serangkaian solusi yang dapat meningkatkan pengetahuan dan keterampilan" (Rosenberg, 2001). E-learning atau Internet enabled learning 
menggabungkan metode pengajaran dan teknologi sebagai sarana dalam belajar. E-learning, "e" atau singkatan dari elektronik dalam E-learning digunakan sebagai istilah untuk segala teknologi yang digunakan untuk mendukung usaha-usaha pengajaran lewat teknologi elektronik internet (Purbo, 2002).

Hartley menyatakan, bahwa e-learning merupakan suatu jenis belajar mengajar yang memungkinkan tersampaikannya bahan ajar ke siswa dengan menggunakan media Internet, Intranet atau media jaringan komputer lain. Sementara Frame Com dalam Glossary of E-learning Terms (Glossary, 2001) menyatakan definisi yang lebih luas, bahwa E- Learning adalah sistem pendidikan yang menggunakan aplikasi elektronik untuk mendukung belajar mengajar dengan media internet jaringan komputer, maupun komputer stand alone. Pemanfaatan internet (TI) dalam pembelajaran tersebut dibagi ke dalam dua tahap, yaitu: pertama, Web Enhanced Course yakni penunjang belajar di kelas (tatap muka) yang dapat diakses secara online dan distance learning yakni peserta dan pengajar terpisah oleh waktu dan ruang (Prakoso, 2005); Kedua, (distance learning) merupakan pengembangan dan tahap pertama, walaupun pada situasi tertentu boleh jadi sebuah institusi baru dapat menerapkan E-Learning pada tahap pertama saja.

Sistem e-learning terdiri dan 3 (tiga) komponen, yaitu Learning Management .Sistem (LMS), e-Content, dan e-Services. Ketiga komponen ini, unfortunately, dilakukan oleh tiga orang pelaksana yang berbeda. LMS, sebagai mesin dan sistem e-learning dibuat oleh berbagai perusahaan swasta (Web City, Blackboard, dan lain- lain) dan ada juga yang dibuat oleh masyarakat dengan menggunakan open source (Moodle, Sakai dan lain-lain). Sedangkan e-Content merupakan materi pembelajaran (learning materials) yang dikembangkan oleh guru, fasilator yang hendak mengajarkan match tersebut kepada muridnya. Untuk mendukung sistem e-learning agar berjalan sesuai dengan yang diharapkan diperlukan tenaga pendukung (supporting stall) yang melakukan dan memberikan layanan elektronis (e-Service). Ketiga pelaksana ini mempunyai karakteristik yang berbeda-beda, sementara yang menjadi objek dan ketiga pelaksana ini adalah students. Interaksi dan ketiga pelaksana tersebut dengan students, sangat erat kaitannya dengan teknologi dan pedagogi yang digunakan. Oleh karena itu, pengembangan dan penggunaan sistem e-learning harus dilakukan secara menyeluruh (holistic), bukan parsial. Manajemen sistem e-learning harus bisa memanfaatkan ketiga petugas pelaksana tersebut agar proses belajar-mengajar (teaching and learning process) berjalan secara optimal. Untuk itu diperlukan suatu mekanisme untuk mengintegrasikan aspek teknologi dan pedagogi dalam sistem e-learning.

\section{Keefektifan Pembelajaran}

Keefektifan berasal dari kata dasar efektif. Dalam Kamus Besar Bahasa Indonesia (2007) kata efektif mempunyai arti ada efek, pengaruh atau akibat. Selain itu efektif juga dapat diartikan dapat membawa hasil, atau berhasil guna. Efektititas pembelajaran merupakan suatu konsep yang lebih luas untuk mencakup berbagai factor di dalam maupun di luar seseorang.Faktor-faktor yang mempengaruhi keefektifan dalam pembelajaran yaitu metode pembelajaran, siswa, situasi, fasilitas dan pengajar itu sendiri. Menurut Sadirman (dalam Trianto, 2009) keefektifan pembelajaran adalah hasil guna yang diperoleh setelah pelaksanaan kegiatan belajar mengajar. Untuk mengetahui 
keefektifan mengajar dapat dilakukan dengan memberikan tes, karena dengan hasil tes dapat dipakai untuk mengevaluasi berbagai aspek proses pengajaran. Soemosasmiti dalam Trianto (2009) menyatakan bahwa suatu pembelajaran dapat dikatakan efektif apabila memenuhi beberapa persyaratan utama keefektifan pembelajaran yaitu (1) Presentasi waktu belajar siswa yang tinggi dicurahkan terhadap KBM (2) Rata-rata perilaku melaksanakan tugas yang tinggi diantara siswa (3) Ketetapan antara kandungan materi ajaram dengan kemampuan siswa (orientasi keberhasilam belajar) diutamakan,dan (4) Mengembangkan suasana belajaran yang akrab dan positif, mengembangkan struktur kelas yang mendukung.

Dari pengertian di atas, apat disimpulkan bahwa keefektifan pembelajaran adalah tingkat keberhasilan dalam pencapaian tujuan pembelajaran. Keefektifan dari penggunakan E-Learning dapat dilihat dari hasil belajar. Jika hasil belajar yang menggunakan E-Learning lebih tinggi dari pembelajaran yang tidak menggunakan e-learning, maka penggunaan $E$ - Learning dikatakan efektif.

\section{Hasil Belajar}

Hasil belajar akan terlihat setelah diberikan perlakuan pada proses belajar. Sudjana (2004) menjelaskan hasil belajar sebagai keberhasilan siswa dalam mempelajari pelajaran di sekolah yang dinyatakan dalam bentuk skor atau nilai yang diperoleh dari hasil test mengenai sejumlah materi tertentu. Hasil belajar merupakan berbagai kapasitas yang diperoleh siswa sehubungan dengan keikutsertaannya dalam proses pembelajaran. Disatu sisi hasil belajar merupakan pencapaian tujuan pengajaran, disisi lain hasil belajar merupakan puncak belajar siswa. Hasil belajar merupakan proses individu yang berinteraksi dengan lingkungan untuk mendapatkan perubahan dalam perilakunya. Perubahan itu diperoleh melalui usaha (bukan karena kematangan), menetap dalam waktu yang relatif lama dan merupakan hasil pengalaman. Hasil belajar seringkali digunakan sebagai ukuran untuk mengetahui seberapa jauh seseorang mengetahui seberapa jauh bahan yang sudah diajarkan. Untuk mengaktualisasikan hasil belajar tersebut diperlukan serangkaian pengukuran alat evaluasi yang baik dan memenuhi syarat (Purnomo, 2011).

Bloom (dalam Kunandar, 2008), "hasil belajar yang dicapai oleh siswa dapat dikelompokkan menjadi 3 (tiga) ranah, yaitu kognitif, afektif, dan psikomotorik". Dalam penelitian ini hasil belajar yang akan di ukur adalah hasil belajar ranah kognitif. Ada enam tingkatan aspek kognitif yang bergerak dari yang sederhana sampai yang kompleks (berdasarkan taksonomi bloom yang sudah direvisi dalam Sugiharto, 2009): 1) remembering, yaitu pengetahuan berdasar ingatan tentang fakta dan data; 2) understanding, yaitu memahami fakta dan data dalam bahasa sendiri; 3) application, yaitu kemampuan menafsirkan atau menggunakan materi pelajaran yang sudah dipelajari ke dalam situasi baru atau konkret; 4) analysis, yaitu kemampuan menguraikan atau menjabarkan sesuatu ke dalam komponen-komponen atau bagian- bagian sehingga susunannya dapat dimengerti; 5) evaluating, yaitu membuat penilaian, ferifikasi, dan rekomendasi berdasarkan kriteria yang ada; 6) creating, yaitu menciptakan sesuatu yang baru dari yang ada.

\section{Hipotesis}

Hipotesis penelitian ini adalah: Terdapat perbedaan signifikan hasil belajar mahasiswa antara kelompok yang menerapkan e-learning dengan kelompok yang tidak menerapkan e-learning. Kelompok yang 
menerapkan e-learning lebih baik hasil belajarnya daripada kelompok yang tidak menerapkan e-learning.

\section{METODE PENELITIAN}

\section{Desain Penelitian}

Penelitian ini menggunakan desain eksperimen semu (Quasi Eksperimen Design) dengan pola noequivalent control group design. Sekelompok subyek yang diambil ditempatkan kedalam kelompok eksperimen dan kelompok kontrol. Kelompok eksperimen diberi treatment khusus dengan pembelajaran model e-learning. Sedangkan kelompok kontrol diberi perlakuan pembelajaran seperti biasa. Kedua kelompok tidak dipilih secara random, tapi ditunjuk langsung karena kelas yang menjadi objek penelitian hanya ada satu ruangan kemudian dibagi menjadi dua kelas. Kedua kelas diberi pre-test dengan soal yang sama untuk mengetahui keadaan awal adakah perbedaan antara kelas eksperimen dan kelas kontrol (Sugiyono, 2014). Hasil pretest yang baik adalah jika nilai kedua kelas tidak berbeda secara signifikan. Dalam penelitian ini kelas yang dijadikan sebagai subjek penelitian adalah semester IV Prodi Teknik Komputer, yang dibagi dua kelas, yaitu kelas eksperimen dan kelas kontrol. Kelas eksperimen adalah kelas A dan kelas kontrol adalah kelas B. Kedua kelas diberikan pembelajaran (e-Learning pada kelas A dan biasa pada kelas B). Diakhir pembelajaran kedua kelas tersebut diberikan suatu test untuk mengetahui hasil belajar. Adapun desain eksperimen nonequivalent control group design dapat dilihat pada Tabel 01 berikut.

Tabel 01 Nonequivalent Control Group Desain

\begin{tabular}{cccc}
\hline Group & Pretest & Perlakuan $(\mathrm{X})$ & Posttest \\
\hline $\mathrm{E}$ & $\mathrm{T}_{1}$ & $\mathrm{x}$ & $\mathrm{T}_{2}$ \\
\hline $\mathrm{K}$ & $\mathrm{T}_{3}$ & & $\mathrm{~T}_{4}$ \\
\hline
\end{tabular}

Sumber: Sugiyono, 2014

\section{Variabel Penelitian}

Variabel dalam penelitian ini terdiri dari independen variabel dan dependen variabel. Independen variabel adalah pembelajaran microprocessor yang dibedakan menjadi dua yaitu pembelajaran e-Learning pada kelas eksperimen dan pembelajaran tanpa e-Learning pada kelas kontrol. Dependen variabel dalam penelitian ini adalah hasil belajar mahasiswa pada mata kuliah arsitektur microprocessor.

\section{Metode Pengumpulan Data}

Pengumpulan data dilakukan dalam berbagai setting, berbagai sumber dan berbagai cara (Sugiyono, 2010:193). Adapun pengumpulan data dalam penelitian ini menggunakan Tes, Observasi dan Dokumentasi.

\section{Tehnik Analisis Data}

Data yang telah terkumpul selanjutnya dilakukan analisis data. Metode analisis data yang digunakan dalam penelitian ini adalah analisis deskriptif untuk mengetahui hasil belajar siswa dari kedua kelompok setelah dilakukan penelitian. Sedangkan analisis kuantitatif dilakukan untuk mengetahui perbedaan penerapan E-learning dengan tanpa E-learning terhadap hasil pembelajaran.

\section{Analisis Uji Hipotesis}

Untuk mengetahui peperbedaan penerapan E-learning terhadap hasil belajar mahasiswa, maka digunakan teknik statistic sebagaimana dikemukakan Sudjana (2005) berikut.

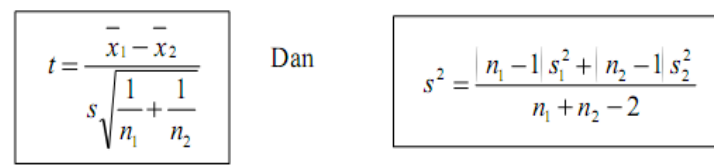

Kriteria pengujian untuk uji perbedaan dua rata-rata pretest menggunakan uji dua pihak, yaitu terima Ho jika $-\mathrm{T} 1-1 / 2 \propto<\mathrm{T} 1-1 / 2 \propto$ dengan $\mathrm{P}$ 
value dan peluang (1- $1 / 2)$, yang berarti $\propto=$ $5 \%$. Dengan diterimanya Ho, berarti nilai rata-rata pretest kelompok eksperimen sama dengan nilai rata-rata pretest kelompok kontrol. Untuk harga-harga $\mathrm{t}$ lainnya Ho ditolak, berarti ada perbedaan nilai rata-rata pretest antara kedua kelompok eksperimen.

Kriteria pengujian untuk uji perbedaan dua rata-rata postest menggunakan uji satu pihak (kiri), dengan $d k=\left(n_{1}+n_{2}-\propto\right)$ yang berarti $\propto=5 \%$ sebagai berikut.

a. Terima $\mathrm{H}_{\mathrm{o}}$ jika $\mathrm{t}_{\text {hitung }}<\mathrm{t}(1-\propto)$, hal ini berarti tidak ada perbedaan nilai rata-rata postest antara kelompok eksperimen dan kelompok kontrol

b. Tolak $H_{o}$ jika $t_{\text {hitung }}>t(1-\propto)$, maka hal ini berarti perbedaan nilai rata-rata postest antara kelompok eksperimen dan kelompok kontrol.

Adapun teknik perhitungan analisis data menggunakan alat bantu komputer dengan program aplikasi SPSS windows for 24 .

\section{PEMBAHASAN}

\section{Analisis Deskriptif Hasil Pretes}

Berdasarkan hasil analisis data pretes terhadap mahasiswa yang berjumlah 25 orang, yang terbagi dalam dua ruangan dimana kelas eksperimen berjumlah 12 orang sedangkan kelas kontrol berjumlah 13 orang.

\section{Deskripsi Nilai Pretes Kelas Eksperimen}

Dari hasil analisis tidak ada mahasiswa yang memperoleh nilai 100 sebagai nilai maksimal. Pada kelas eksperimen hanya 1 orang yang mencapai nilai 5 sebagai nilai maksimal. Sedangkan nilai terendah adalah 1 yang dicapai oleh 2 orang.

Tabel 02 Disribusi Frekuensi Nilai Pretes

\begin{tabular}{ccc}
\hline Nilai & Frequency & Percent \\
\hline 5 & 4 & 33,3 \\
4 & 3 & 25 \\
3 & 2 & 16,66
\end{tabular}

\begin{tabular}{ccc}
2 & 2 & 16,66 \\
1 & 1 & 8,33 \\
\hline Total & 12 & 100.0 \\
\hline \multicolumn{2}{l}{ Sumber Data: Olahan SPSS } & 2016
\end{tabular}

Tebel 02 menunjukkan bahwa pada kelas eksperimen ada 4 orang yang memperoleh nilai $5(33,3)$ sebagai nilai tertingginya. Selanjutnya yang mendapat nilai 4 berjumlah 3 orang (25\%), yang mendapat nilai 3 berjumlah 2 orang $(16,66 \%)$, yang mendapat nilai 2 berjumlah 2 orang $(16,66 \%)$. Yang mendapat nilai 1 berjumlah 1 orang $(8,33)$. Frekuensi perolehan nilai tersebut ditunjukan dalam bentuk diagram batang berikut.

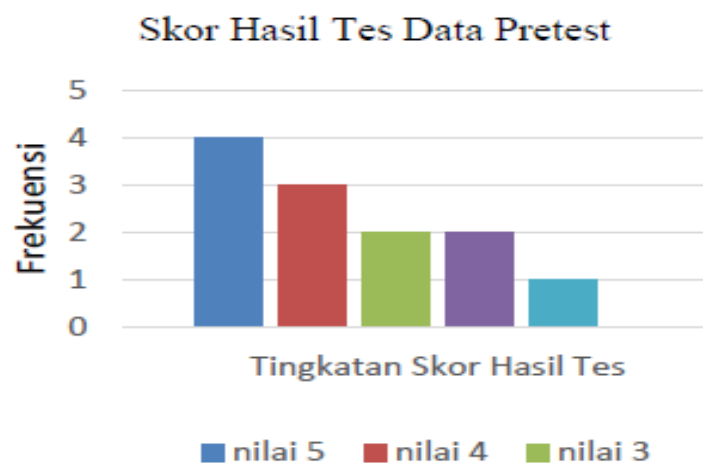

Gambar 01 : Nilai Pretes Kls. Eksperimen

2. Deskripsi Nilai Pretes Kelas Kontrol

Hasil analisis pada kelas kontrol diketahui tidak ada mahasiswa yang memperoleh nilai 10 sebagai nilai maksimal. Nilai terendah adalah 1 yang diperoleholeh 1 orang.

Tabel 03 Disribusi Frekuensi Nilai Pretes

\begin{tabular}{ccc}
\hline Nilai & Frequency & Percent \\
\hline 5 & 2 & 15,38 \\
4 & 3 & 27,07 \\
3 & 2 & 15,38 \\
2 & 3 & 23,07 \\
1 & 3 & 23,07 \\
Total & 13 & 100.0 \\
\hline
\end{tabular}

Sumber: Olahan SPSS 2016 
Tabel 03 menunjukkan bahwa nilai tertinggi yang diperoleh mahasiswa, yaitu 5 yang dicapai oleh 2 orang $(15,38)$. Yang mendapat nilai 4 berjumlah 3 orang $(15,38 \%)$, yang mendapat nilai 3 berjumlah 2 orang $(15,38 \%)$, yang mendapat nilai 2 berjumlah 3 orang $(27,07 \%)$. Yang mendapat nilai 1 berjumlah 3 orang $(27,07)$. Frekuensi perolehan nilai tersebut ditunjukan dalam bentuk diagram batang berikut.

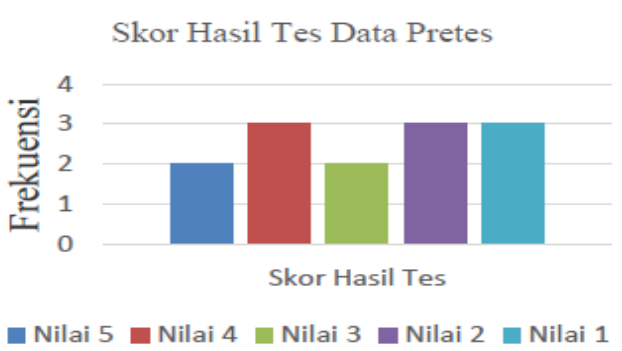

Gambar 02 : Hasil Pretes Kelas Kontrol

Berdasarkan analisis deskripsi di atas, diketahui kondisi awal kedua kelas dengan nilai rata-rata pretest relative tidak berbeda. Dengan demikian dapat disimpulkan bahwa kondisi awal kedua kelas penelitian memiliki kemampuan yang relatif sama dan berada pada kategori kurang.

\section{Analisis Deskriptif Hasil Belajar Kognitif Mahasiswa}

Hasil analisis deskripstif setelah diberikan perkuliahan melalui e-learning pada kelas eksperimen dan tanpa e-learning pada kelas kontrol menunjukkan adanya perbedaan hasil belajar kognitif mahasiswa.

Berdasarkan hasil analis data hasil belajar mahasiswa (postes) yang berjumlah 25 mahasiswa, yang terbagi dalam dua ruangan, dimana kelas eksperimen berjumlah 12 mahasiswa sedangkan kelas kontrol berjumlah 13 mahasiswa. Hasil analisis deskriptif masing-masing kedua kelas tersebut diuraiakan berikut ini.

1. Analisis Hasil Belajar Kognitif Mahasiswa pada Kelas Eksperimen
Dari hasil analisis tidak ada mahasiswa yang memperoleh skor 10 sebagai nilai maksimal. Pada kelas eksperimen hanya 1 orang yang mencapai nilai 9 dan 2 mahasiswa yang memperoleh nilai terendah 1 .

Tabel 04 Disribusi Frekuensi Nilai Postes

\begin{tabular}{ccc}
\hline Nilai & Frekuensi & Persen \\
\hline 9 & 10 & 83,33 \\
8 & 1 & 8,33 \\
7 & 1 & 8,33 \\
\hline Total & 12 & 100
\end{tabular}

Sumber: Olahan SPSS 2016

Tebel 04 menunjukkan bahwa nilai tertinggi yang diperoleh mahasiswa pada kelas eksperimen sebesar 9 berjumlah 10 orang $(83,33)$ selanjutnya mahasiswa yang mendapat nilai 8 berjumlah 1 mahasiswa $(8,33 \%)$, dan mahasiswa yang mendapat nilai 7 berjumlah 1 mahasiswa $(8,33 \%)$.

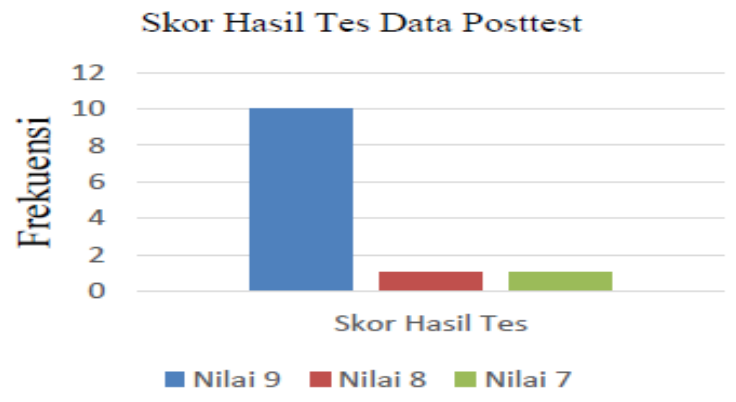

Gambar 03 : Frekuensi Skor Posttes

2. Analisis Hasil Belajar Kognitif Mahasiswa pada Kelas Kontrol

Hasil analisis pada kelas kontrol diketahui tidak ada mahasiswa yang memperoleh nilai 10 sebagai nilai maksimum. Nilai tertinggi yang diperoleh mahasiswa adalah 7 yang dicapai oleh 5 orang. Nilai terendah yang diperoleh oleh mahasiswa adalah 5 yang dicapai oleh 4 orang.

Tabel 05 Disribusi Frekuensi Skor Postes

\begin{tabular}{rcc}
\hline Nilai & Frekuensi & Persen \\
\hline 7 & 4 & 30,76 \\
6 & 3 & 23,07
\end{tabular}




\begin{tabular}{ccc}
5 & 6 & 21,30 \\
\hline Total & 13 & 100.0 \\
\hline
\end{tabular}

Sumber: Olahan Peneliti 2016

Tabel 05 menunjukan bahwa skor tertinggi yang diperoleh mahasiswa kelas kontrol sebesar 7 berjumlah 4 orang $(30,76 \%)$. Selanjutnya mahasiswa yang mendapat skor 6 berjumlah 3 orang $(23,07 \%)$, mahasiswa yang mendapat skor 5 sebanyak 6 mahasiswa $(21,30 \%)$.

Skor Hasil Tes Kognitif Data Posttest

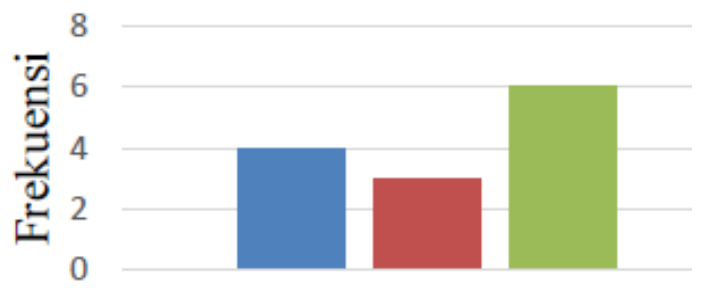

Skor Hasil Tes

Skor 7 Skor 6 Skor 5

Gambar 04 : Hasil Postes Kelas Kontrol

\section{Perbandingan Nilai Hasil Belajar}

Nilai hasil belajar siswa diperoleh dari persentase skor hasil tes, yaitu perbandingan antara skor yang diperoleh dengan skor maksimal dikali 100 (skor yang diperoleh/skor maksimal $X \quad 100)$. Berdasarkan hasil analisis data posttest diketahui bahwa hasil belajar siswa kelas eksperimen yang menggunakan e-learning lebih baik daripada hasil belajar siswa kelas kontrol tanpa e-learning.

\begin{tabular}{|c|c|c|c|c|c|}
\hline \multirow{2}{*}{ Rentang Nilai } & \multicolumn{2}{|c|}{ Eksperimen } & \multicolumn{2}{|c|}{ Kontrol } & \multirow{2}{*}{ Predikat } \\
\hline & $\mathrm{F}$ & $\%$ & $\mathrm{~F}$ & $\%$ & \\
\hline $90 \leq 100$ & 10 & 83,33 & . & . & Sangat Baik \\
\hline $80<90$ & 1 & 8,33 & - & . & Baik \\
\hline $70 \leq 80$ & 1 & 8,33 & 4 & 30,76 & Cukup \\
\hline$<70$ & - & - & 9 & 69,24 & Kurang \\
\hline
\end{tabular}

Sumber: Hasil Olahan Peneliti 2016
Berdasarkan analisis hasil belajar mahasiswa dalam mengikuti mata pelajaran microprocessor mahasiswa pada kelas eksperimen terlihat lebih baik daripada mahasiswa pada kelas kontrol. Hal ini ditunjukkan oleh persentase hasil belajar mahasiswa kelas eksperimen dimana terdapat 10 orang $(83,33 \%)$ kategori mahasiswa sangat baik, sedangkan pada kelas kontrol hanya tidak ada kategori mahasiswa yang sangat baik. Terdapat 1 siswa $(8,33 \%)$ siswa kelas eksperimen pada kategori baik, sedangkan pada kelas kontrol terdapat tidak terdapat. Pada kelas eksperimen hanya terdapat 1 mahasiswa $(8,33 \%)$ kategori cukup, sedangkan pada kelas kontrol terdapat 4 mahasiswa $(30,76 \%)$. Pada kelas eksperimen tidak terdapat mahasiswa yang memperoleh nilai dibawah 70 , sedangkan pada kelas kontrol terdsapat $9 \quad(69,24)$ mahasiswa yang memperoleh nilai di bawah 70. Hasil belajar mahasiswa pada kelas eksperimen dan kelas kontrol tampak pada diagram batang berikut

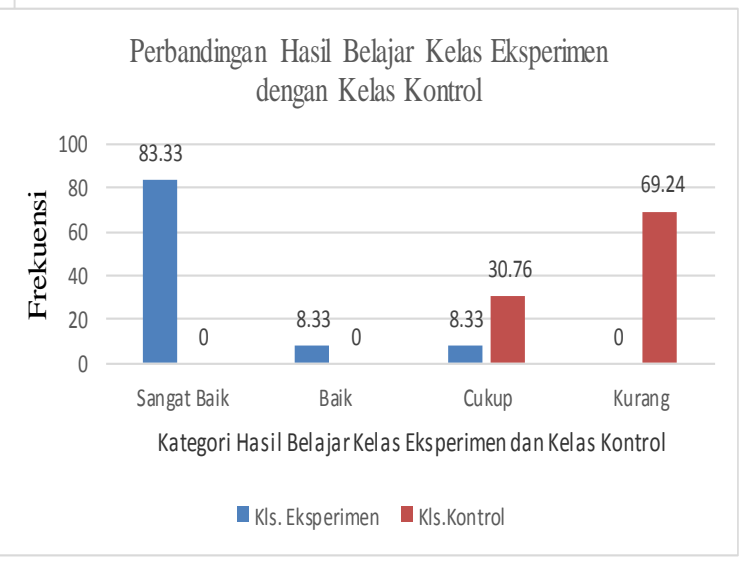

Gambar 05 Hasil Postes Kelas Kontrol

\section{Uji Hipotesis}

1. Hasil Uji Perbedaan Rata-Rata Hasil Belajar

Setelah mendapat perlakuan yang berbeda, yaitu pembelajaran dengan menggunakan E-learning pada kelompok eksperimen dan pembelajaran tanpa 
E-learning pada kelompok kontrol, terlihat bahwa rata-rata nilai mata pelajaran lingkungan hidup kedua kelompok memiliki perbedaan yang cukup signifikan. Hal ini ditunjukkan dari hasil uji Two Independent Samples Tests (metode uji Mann Whitney U), maka diperoleh gambaran perbedaan hasil belajar kedua kelompok tersebut seperti pada Tabel 07 berikut.

Tabel 07 Hasil Uji Two Independent Samples Tests Data Posttest

\begin{tabular}{lc}
\hline & Hasil Posttest \\
\hline Mann-Whitney U & 200.500 \\
Wilcoxon W & 696.500 \\
Z & -3.958 \\
Asymp. Sig. (2-tailed) & .000 \\
Exact Sig. (2-tailed) & .000 \\
Exact Sig. (1-tailed) & .000 \\
Point Probability & .000 \\
\hline
\end{tabular}

Sumbel: Olahan Peneliti 2016

Melalui kesamaan rata-rata dengan menggunakan uji Two Independent Samples Tests diperoleh nilai Mann Whitney $\mathrm{U}=$ 200,500; Wilcoxon $\mathrm{W}=696,500$; $\mathrm{Z}$ sebesar -3, 958 Asymp sig. sebesar 0,000; dan Exact Sig. sebesar 0,000.

Kriteria pengujian jika nilai signikansi < 0,05, maka hipotesis $\mathrm{H}_{0}$ ditolak dan hipotesis $\mathrm{H}_{1}$ diterima. Jika nilai signifikansi > 0,05, maka $\mathrm{H}_{0}$ diterima. Dalam penelitian ini terbukti bahwa signifikansi (Asymp sig) senilai 0,000, dengan demikian hipotesis $\mathrm{H}_{0}$ yang menyatakan tidak ada perbedaan hasil belajar mahasiswa antara kelas yang menerapkan pembelajaran menggunakan model E-learning dari pada kelas yang menerapkan pembelajaran tanpa model E-learning ditolak dan $\mathrm{H}_{1}$ yang menyatakan ada perbedaan hasil Belajar mahasiswa antara kelas yang menerapkan pembelajaran menggunakan model E-learning dari pada kelas yang menerapkan pembelajaran tanpa model E-learning diterima. Artinya terdapat perbedaan hasil belajar mahasiswa pada data posttest dari kedua kelompok tersebut.

2. Hasil Uji Perbedaan Rata-Rata Keaktifan Mahasiswa

Hasil Uji terhadap proses pembelajaran kedua kelas dengan perlakuan yang berbeda pada mata pelajaran arsitektur mocro processor. Pada kelas eksperimen menerapkan model pembelajaran E-learning sedangkan pada kelas kontrol menerapkan pembelajaran tanpa model E-learning. Hasil analisis uji beda menggunakan teknik statistic uji Two Independent Samples Tests (metode uji Mann Whitney U), maka diperoleh gambaran seperti pada Tabel 08 berikut.

Tabel 08 Hasil Uji Two Independent Samples Tests

\begin{tabular}{lc}
\hline & Keaktifan Belajar \\
\hline Mann-Whitney U & 97.500 \\
Wilcoxon W & 593.500 \\
$\mathrm{Z}$ & -5.429 \\
Asymp. Sig. (2-tailed) & .000 \\
Exact Sig. (2-tailed) & .000 \\
Exact Sig. (1-tailed) & .000 \\
Point Probability & .000 \\
\hline
\end{tabular}

Sumber : Olahan Peneliti 2016

Melalui kesamaan rata-rata dengan menggunakan uji Two Independent Samples Tests diperoleh nilai Mann Whitney $\mathrm{U}=$ 97,500; Wilcoxon $\mathrm{W}=593,500$; Z sebesar -5 , 429 Asymp sig. sebesar 0,000; dan Exact Sig. sebesar 0,000 .

Kriteria pengujian jika nilai signikansi < 0,05, maka hipotesis $\mathrm{H}_{0}$ ditolak dan hipotesis $\mathrm{H}_{1}$ diterima. Jika nilai signifikansi > 0,05, maka $\mathrm{H}_{0}$ diterima. Dalam penelitian ini terbukti bahwa signifikansi (Asymp sig) senilai 0,000 , dengan demikian hipotesis $\mathrm{H}_{0}$ yang menyatakan tidak ada perbedaan keaktifan belajar mahasiswa antara kelas yang menerapkan pembelajaran menggunakan model E-learning dari pada 
kelas yang menerapkan pembelajaran tanpa model E-learning ditolak dan $\mathrm{H}_{1}$ yang menyatakan ada perbedaan keaktifan belajar mahasiswa antara kelas yang menerapkan pembelajaran menggunakan model E-learning dari pada kelas yang menerapkan pembelajaran tanpa model E-learning diterima. Artinya terdapat perbedaan keaktifan belajar mahasiswa pada kedua kelompok tersebut.

\section{Pembahasan}

Setelah mendapat perlakuan yang berbeda dalam pembelajaran komputer materi arsitektur microprocessor, yaitu pembelajaran menggunakan model e-learning pada kelas eksperimen dan pembelajaran tanpa menggunakan e-learning pada kelas kontrol, tampak adanya perbedaan keaktifan siswa diantara kedua kelas tersebut. Melalui uji beda menggunakan uji Two Independent Samples Tests diperoleh nilai Mann Whitney $\mathrm{U}=200,500 ;$ Wilcoxon $\mathrm{W}=696,500 ; \mathrm{Z}$ sebesar -3, 958 Asymp sig. sebesar 0,000; dan Exact Sig. sebesar 0,000. Hal ini membuktikan adanya perbedaan hasil belajar siswa pada data posttest dari kedua kelas tersebut.

Analisis deskriptif menunjukkan pada kelas eksperimen tidak ada mahasiswa yang berada pada kategori kurang. Sedangkan pada kelas control terdapat 9orang atau 69,24\% yang berada pada kategori kurang. Pada kelas eksperimen hanya terdapat 1 $(8,33 \%)$ orang yang berada pada kategori cukup. Sedangkan pada kelas control terdapat 4 orang atau $30,76 \%$ yang berada pada kategori cukup. Pada kelas eksperimen terdapat 1 orang yang berada pada kategori baik, sedangkan pada kelas control tidak terdapat mahasiswa yang berada pada kategori baik. Pada kelas eksperimen terdapat 10 orang atau $83,33 \%$ mahasiswa yang berada pada kategori sangat baik, sedangkan pada kelas control tidak ada mahasiswa yang berada pada kategori sangat baik.

Penelitian menemukan perbedaan signifikan hasil belajar mahasiswa antara yang menggunakan model e-learning dengan pembelajaran tanpa menggunakan model e-learning. Dimana pembelajaran yang menggunakan e-learning jauh lebih baik dari pembelajaran tanpa menggunakan e-learning. Dengan demikian dapat dikatakan bahwa pembelajaran model e-learning sangat efektif diterapkan dalam pembelajaran materi arsitektur microprocessor. Temuan penelitian ini sejalan jengan pendapat Vaugran Waller, 2001 yang menyatakan e-Learning adalah proses belajar yang efektif yang dihasilkan dengan cara menggabungkan penyampaian materi secara digital yang terdiri dari dukungan dan layanan dalam belajar. Karena dalam penerapan e-Learning terlihat hasil belajar yang dicapai siswa lebih tinggi daripada kelas yang tidak menerapkan e-Learning. Sehingga dapat dikatakan penerapan e-Learning berbasis dapat di katakan efektif.

\section{KESIMPULAN}

Berdasarkan hasil analisis data dan pembahasan, kesimpulan yang dapat diambil dari penelitian ini yaitu: 1). Penerapan e-Learning pada pembelajaran microprocessor di Politeknik Sains dan Teknologi WIratama Maluku Utara sangat efektif karena hasil penelitian menunjukkan perbedaan antara kelas yang menggunakan e-Learning dengan kelas tanpa e-Learning berbasis. 2). Analisis deskriptif tentang hasil belajar siswa pada pembelajaran microprocessor menggunakan e-Learning, terjadi peningkatan hasil belajar yang lebih baik. Hal ini dapat dilihat dari meningkatnya presentase hasil belajar siswa pada kelas yang menerapkan e-learning lebih tinggi daripada kelas yang tidak menerapkan e-learning. 
Dari hasil kesimpulan pada penelitian ini dapat disarankan Penerapan e-learning dalam pembelajaran baik digunakan di Politeknik Sains dan Teknologi Wiratama Maluku Utara agar meningkatkan keaktifan dan hasil belajar siswa. Untuk itu diharapkan kepada Politeknik untuk meningkatkan kapasitas infrastruktur jaringan agar praktik e-learning dalam pembelajaran dapat berlangsung efektif.

\section{DAFTAR PUSTAKA}

Barbara B. Seels \& Rita C. Richey.1994. Teknologi Pembelajaran Jakarta : Unit

Mayub, A. 2004. E-Learning Fisika Berbasis Macromedia Flash MX, Sudjana 2004. Dasar - Dasar Proses Belajar Mengajar. Bandung: Sinar Baru Algensindo

Sudjana, 2005. Dasar - Dasar Proses Belajar Mengajar. Bandung: Sinar Baru Algensindo.

Kunandar., 2008, Langkah Muda Penelitian Tindakan Kelas Sebagai Pengembangan Profesi Guru. Raja Grafindo Persada. Jakarta

Purwanto, 2011. Evaluasi Hasil Belajar. Pustaka Belajar. Yogyakarta.

Glossary, 2012. Glossaryofe - Learning Terms (online) available at: http:// LearnFrame.Com

Sugiyono 2014. Metode Penelitian Pendidikan (Pendekatan Kuantitatif, Kualitatif, dan $R \& D)$. Bandung: ALFABE.

Zyainuri dan Eko Marpanaji, Penerapan E-Learning Moodle untuk pembelajaran siswa yang melaksanakan Prakerin, Jurnal Pendidikan Vokasi, Vol 2, Nomor 3, November 2012

Neni Yuniati, Bambang Eka Purnama, Gesang Kristianto Nugroho, Pembuatan Media Pembelajaran Interaktif Ilmu Pengetahuan Alam Pada Sekolah Dasar
Negeri Kroyo 1 Sragen, Jurnal on Computer Science - Speed (IJCSS) 12 Vol 9 No 1, Februari 2012, ISSN 1979 9330

Arisandy Ambarita, Implementasi Sistem E-Learning Menggunakan Software Moodle Pada Politeknik Sains dan Teknologi Wiratama Maluku Utara, IJIS - Indonesian Journal On Information System Volume 1 Nomor 2, September 2016 